\title{
Clay resources in the Netherlands
}

\section{M.J. van der Meulen ${ }^{*}$, D. Maljers, S.F. van Gessel \& S.H.L.L. Gruijters}

TN0 Built Environment and Geosciences - Geological Survey of the Netherlands, P0 Box 80015, NL-3508 TA Utrecht, the Netherlands.

* Corresponding author. Email: michiel.vandermeulen@tno.nl

Manuscript received: October 2006; accepted: June 2007

\begin{abstract}
Clay is a common lithology in the Dutch shallow subsurface. It is used in earth constructions such as dikes, and as raw material for the fabrication of bricks, roof tiles etc. We present a new national assessment of Dutch clay resources, as part of a project that provides mineral-occurrence information for land-use planning purposes. The assessment is based on a 3D geological model, which consists of voxel cells with lithological composition as primary attribute, and has been obtained by interpolating data of more than 380,000 digital borehole descriptions. The occurrence of shell material and the extent to which clay is peaty were used as quality attributes, enabling us to tentatively distinguish between clay that is potentially suitable as ceramic material, and clay that is not.

As clay is extracted using dry (i.e. non-dredging) techniques, the model space has been dimensioned to fully encompass the unsaturated zone. A high-resolution model (with voxel cells of $250 \cdot 250 \cdot 0.2 \mathrm{~m}$ ), based mainly on abundant, good-quality hand drillings, was constructed down to $3 \mathrm{~m}$ below the surface. This depth range suffices for clay-resource assessments in the lowlands, which have relatively high groundwater levels. Cells from a lower-resolution model $(250 \cdot 250 \cdot 1 \mathrm{~m}$, based on fewer data) were added to reach appropriate depths in upland areas.

We arrive at about $42.1 \mathrm{~km}^{3}$ of clay occurring in the model space (land areas only). Clay occurs mainly in the coastal domain and below the Rhine and Meuse river plains. Geological exploitability has been assessed within the unsaturated zone, taking overburden and intercalations with non-clay materials (especially peat) into account. The resulting exploitable stock is 12.3 to $18.0( \pm 2.0) \mathrm{km}^{3}$; an estimate in which the main source of uncertainty is presented by a lack of proper groundwater-table data. This amount equates to roughly 6000 annual consumption equivalents. Even when considering that the larger part of the clays is unsuitable for firing, and about one quarter is situated below built-up lands or nature preserves, clay is not a scarce resource in the Netherlands and supplies should present no problem in the near future.
\end{abstract}

Keywords: Netherlands, clay, resource assessment, building materials, construction materials, structural-ceramics industry, earth constructions

\section{Introduction}

Clay is a versatile mineral raw material: malleable when moist, cohesive after drying, and rock-hard when fired. It is applied as such in earth constructions that are durable and impermeable to water, and it is used as raw material for ceramicproduct manufacturing. In the Netherlands, clay occurs abundantly and it is accordingly important as building and construction material. Even though the last decades have seen an ever-increasing use of concrete, clay bricks and roof tiles still determine the face of any Dutch town. Current Dutch clay consumption is 2 to $3 \mathrm{Mt} / \mathrm{a}$ (Fig. 1). About two thirds of this amount is used by the structural-ceramics industry, and one third is used in construction, mainly for dike building and maintenance (Van der Meulen et al., in press). The Netherlands is virtually self-supporting for clay (Van der Meulen et al. 2003a). Small amounts are imported, mainly from Germany, in order to supplement Dutch ceramic clays with materials having some special property.

The Dutch Ministry of Spatial Planning, Housing and the Environment has recently introduced a so-called building materials assessment ('bouwgrondstoffentoets'; Anonymous, 2004; Van der Meulen, 2005a), in order to arrange for a certain level of access to sparse surface mineral resources. It involves 


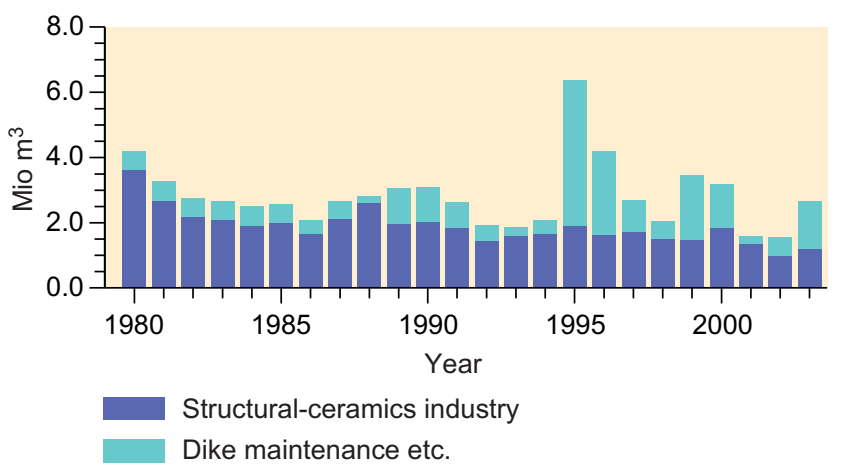

Fig. 1. Dutch clay production between 1980 and 2003 (Van der Meulen et al., In press). The peak in the mid-1990s reflects a dike-reconstruction programme, which was undertaken after imminent river floods in 1993 and 1995.

the identification of mineral resources when preparing for building or land-reconstruction projects (that is, outside areas that are already built-up), and it requires taking mineral resources and interests into consideration in the planning process (e.g. Van der Meulen et al., 2004, 2005b). The aim of the assessment is to avoid (unintended) sterilisation of resources, and to stimulate their exploitation in conjunction with the project that is assessed. Clay for the structuralceramics industry is one of the mineral types that are considered scarce.

Conducting the assessment requires the use of geological information. We present a new assessment of clay resources in the Netherlands, including estimates of the size of the exploitable stocks. The results of this study will be used for 'Delfstoffen Online' (Minerals Online): a nation-wide, web-based minerals information system that is currently being developed as a tool for the building materials assessment (TN0 2007a).

\section{Geological setting}

Most superficial clays in the Netherlands are of Holocene age, and deposited in fluviatile to shallow marine sedimentary environments (Fig. 2). Older clays occur at or near the surface in the uplands of the provinces of Limburg (Tertiary fluviatile and marine clays), Gelderland and Zeeland (Rupelian marine clays). Quaternary brook deposits in Noord-Brabant, Gelderland, Overijssel and Limburg are resources of secondary importance, which were exploited mainly historically, when the structuralceramics industry was spread all over the country, supplying local markets. Pleistocene loess deposits in Limburg, no clay
Fig. 2. Simplified geological map of the Netherlands, modified from Weerts et al. (2004). 'KNB members' belong to the Royal Association of Dutch Brick Producers (Koninklijk Verbond van Nederlandse Baksteenproducenten, based in Velp), which represents the larger part of Dutch structural-ceramics industry.

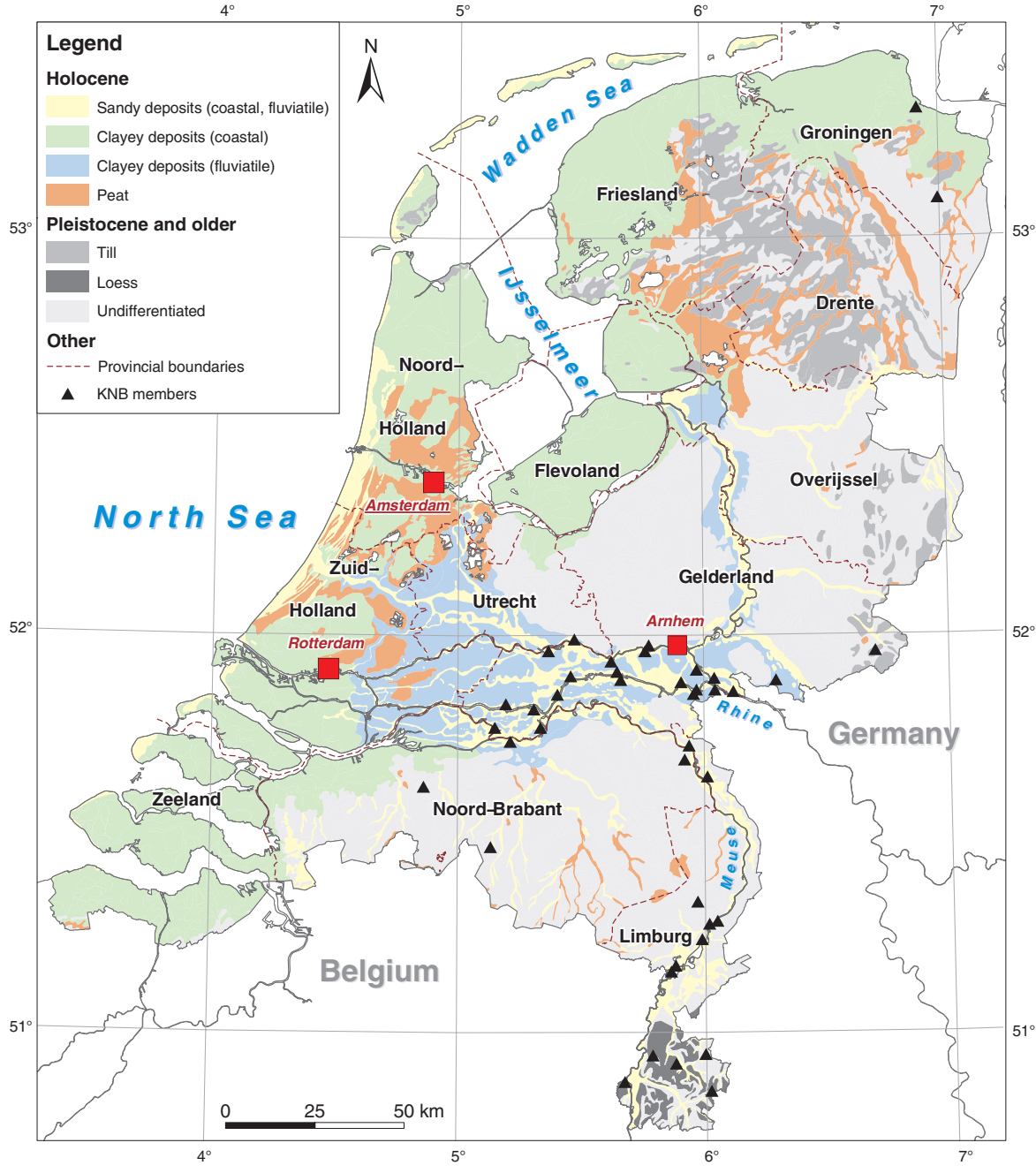


resource in the geological sense, are exploited on a minor scale for a variety of purposes, including ceramic-product fabrication.

At present, Dutch brick and roof-tile producers extract about two-thirds of their clay along the rivers Rhine and Meuse (Sigmond et al., 2001). Clay is deposited at relatively high rates within the confinement presented by the lowlands' river dikes, and by the valley flanks of the upstream Dutch Meuse (e.g. Van der Meulen et al., 2006).

\section{Data and criteria}

\section{Borehole data}

The present clay-resource assessment is based mainly on borehole data in DINO, the Dutch national database for geological data and information, developed and maintained by the Geological Survey of the Netherlands (Kooijman, 2003; Peersmann, 2005). It has the advantage of being the single largest dataset of its kind in the country, offering national coverage. DIN0 currently contains more than 380,000 borehole descriptions, i.e. $\sim 9$ per $\mathrm{km}^{2}$ on average (Fig. 3). This number includes our own boreholes, most of which were drilled for geological mapping purposes, and third-party data. All of the descriptions were selected for processing. While the available data are satisfactory for regional to national-scale work, their quality presents some limitations to our study in terms of accuracy and definition issues.

\section{Assessing resources with non-dedicated data}

Clay is relatively easy to identify in the field, but there are several formal and informal definitions that differ considerably (Van der Meulen et al., 2003b). Clay may be defined according to grain size (e.g. the share of lutum: particles $<2 \mu \mathrm{m}$ ), mineralogy (clay-mineral association) or geotechnical behaviour (cohesive, plastic when moist, etc.).
Dutch structural-ceramics industry primarily defines clay by the share of particles $<10 \mu \mathrm{m}$, a range that comprises not only the lutum fraction, according to which clay is defined geologically, but also the fine silt fraction. Beyond that, a number of physical and chemical properties are relevant for raw-material characterisations. Modern production efficiency and quality control require optimised production processes and materials, which have to comply with narrowly defined specifications. Rather than firing available clay from local resources, as was customary in the past, clays from different locations or stratigraphic levels are mixed to meet such specifications. Accordingly, assessing the quality of clay as ceramic material has come to be a rather specialised undertaking. The industry funds a dedicated research institute (TCKI, based in Velp), which makes such assessments in the context of the complete ceramic-product process chain: raw materials properties and handling, drying and firing processes, and endproduct specifications such as strength, durability, colour and texture. These are determined largely by the clay chemistry and mineralogy, and by the sand and organic-matter contents (Van der Zwan, 1990; Van Wijck, 1997; Table 1). Customer demands for certain colours or textures are important to the industry, and these are determined mainly by the iron and carbonate contents. Shells, calcareous nodules, peat, plant debris or rootlets are deleterious impurities that increase the chance of failure during production or use.

The quality of borehole data in DINO reflects the original purpose of the drilling, the drilling and description methods, the qualifications of the personnel involved, etc. Even in the best category, however, the descriptions do not meet industrial standards for clay-prospecting. Not all relevant parameters are included, and most of the ones that are were not determined with sufficient accuracy. Shares of lutum, silt and sand, for instance, are commonly estimated grain-size or admixture classes, rather than discrete values determined by laboratory analyses. Organic matter and carbonate contents are either

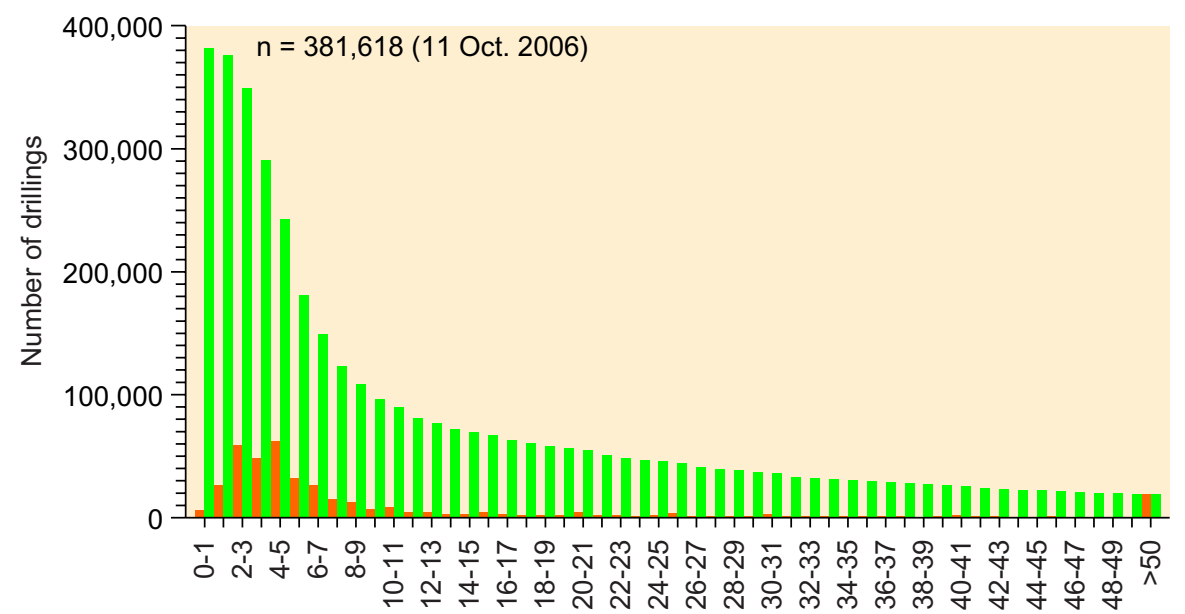

End depth class $(\mathrm{m})$
Fig. 3. Orange bars: histogram of the end depth of the drilling data used in our study. Green bars: the total number of drillings available per metre interval. 
Table 1. Approximate requirements for clay in the structural-ceramics industry and for dike maintenance. Note that clay in the industrial definition may include loam (/silt). Modified from Van der Zwan (1990).

\begin{tabular}{|c|c|c|c|c|c|c|c|}
\hline \multirow[t]{2}{*}{ Application } & \multicolumn{5}{|c|}{ Share of grain-size fraction $(\% \mathrm{~m} / \mathrm{m})$} & \multirow{2}{*}{$\begin{array}{l}\text { C-org } \\
(\% \mathrm{~m} / \mathrm{m})\end{array}$} & \multirow{2}{*}{$\begin{array}{l}\mathrm{CaCO}_{3} \\
(\% \mathrm{~m} / \mathrm{m})\end{array}$} \\
\hline & Lutum & $<10 \mu \mathrm{m}$ & $63-250 \mu \mathrm{m}$ & $\geqslant 250 \mu \mathrm{m}$ & Sand & & \\
\hline Roof tiles & & $50-57$ & $<20$ & $<40$ & & $<3$ & $<25$ \\
\hline Bricks & $40-42$ & $<20$ & $<40$ & & $<3$ & $<25$ & \\
\hline Extruded products & & $40-55$ & $<20$ & $<40$ & & $<3$ & $<25$ \\
\hline Dike maintenance & $18-40$ & & & & $<40$ & $<3$ & \\
\hline
\end{tabular}

not quantified, or given as abundance classes based on visual estimates. The number of chemical analyses in our database is negligible. Because of these limitations, we focussed on properties that inhibit ceramic-product fabrication, rather than attempting to map quality parameters. This approach is consistent with the scale and purpose of our assessment, which is tuned to regional planning and pre-prospecting.

Clay specifications for earthworks are related largely to the desired cohesiveness and impermeability, and are less stringent than those for the ceramic industry (Table 1). Locally extracted clay is used wherever possible, so for this application we expect to provide sufficient information with the combination of resource distribution and clay properties that can be derived from non-dedicated geological data.

\section{Resource definition}

In principle, clay in our database is defined according to NEN 5104 (Anonymous, 1989, 1990). This official Dutch sedimentsample classification system is based on a set of three ternary diagrams (Fig. 4). The first of these, in which the shares of the gravel ( $\geqslant 2 \mathrm{~mm})$, sand $(63-2000 \mu \mathrm{m})$, and lutum + silt $(<63 \mu \mathrm{m})$ fractions are plotted, is used to determine whether or not a sample classifies as gravel. The second diagram, of the shares of organic matter, lutum, and sand + silt, is used to determine whether or not a sample is peat. If not, the third diagram is used to distinguish between sand, loam and clay (note that silt is no sediment type in the Dutch classification; the term refers to a fraction only).
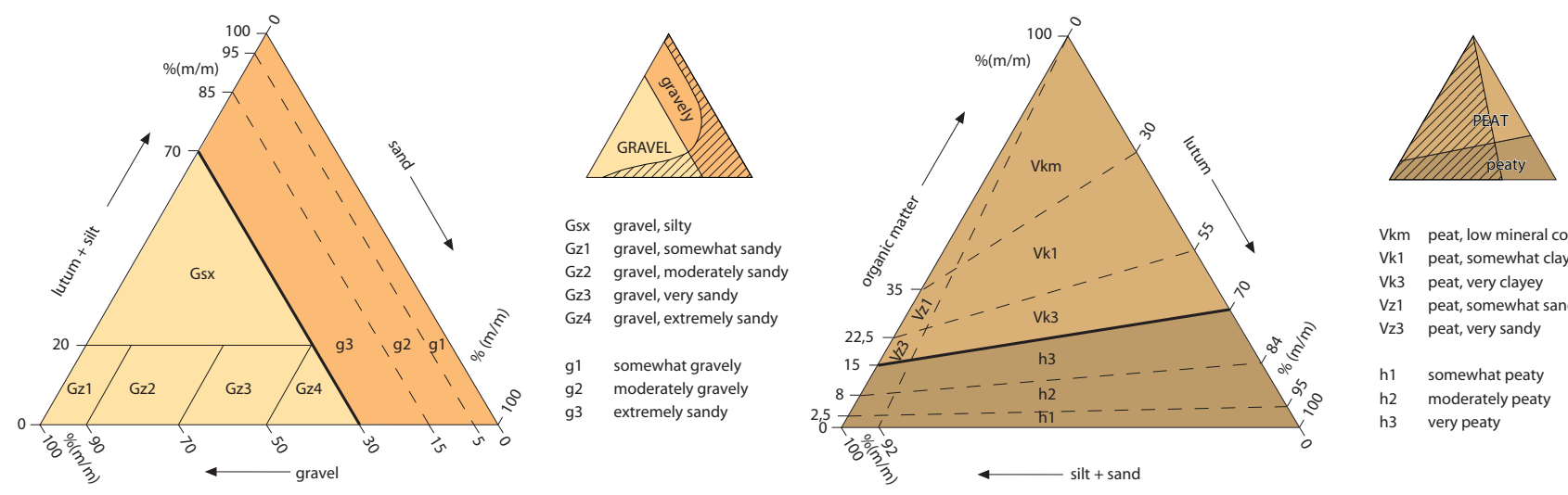

Gsx gravel, silty

Gz1 gravel, somewhat sand

Gz2 gravel, moderately sand

Gz3 gravel, very sandy

Gz4 gravel, extremely sandy

g1 somewhat gravely 2 moderately gravely extremely sandy

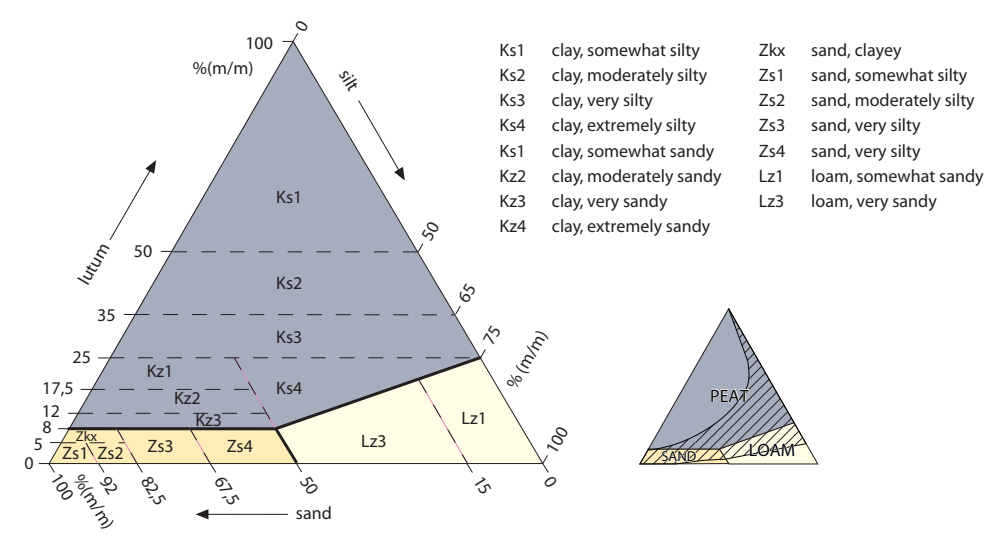

Vkm peat, low mineral content Vk1 peat, somewhat clayey Vk3 peat, very clayey Vz1 peat, somewhat sandy Vz3 peat, very sandy

h1 somewhat peaty h2 moderately peaty h3 very peaty

Fig. 4. Ternary diagrams of the Dutch soil classification system, modified from anonymous (1989, 1990); see text and Van der Meulen et al. (2003b) for explanation. Hatching indicates naturally occurring sediments. 
As raw material, clay may include sediments that geologists would classify as loam (or silt) rather than clay. Our inventory has to be based on geological data and classifications, but keeping the industrial definition of clay in mind. In the terms used in our database, we consider clay, sandy clay, loam (which includes loess) and sandy loam to be clay resources. We distinguish between fine and coarse resource categories, i.e. clay s.s. and the other clayey lithologies, respectively.

\section{Modelling approach}

\section{Model setup}

Van der Meulen et al. (2005) presented a 3D lithological model (further referred to as 'aggregates model'), which was built for a national re-assessment of aggregate resources. We refer to this publication and references therein for the generalities of data handling and model building. The modelling procedure, a 3D interpolation of drilling data into a voxel model with pertinent cell attributes (i.e. the shares of gravel, sand, clay/ loam, peat and 'other' material), is summarised in Figure 5. The main effort of the present study has been put in dealing with the limitations of the aggregates model for use in a clayresource assessment (resolution and confidence).

\section{Exploitability practices and model dimensions}

Clay is usually extracted using earth-moving equipment such as backhoes. With virtually no exception, dredging techniques are not used, as dewatering and regaining a more or less normal clay

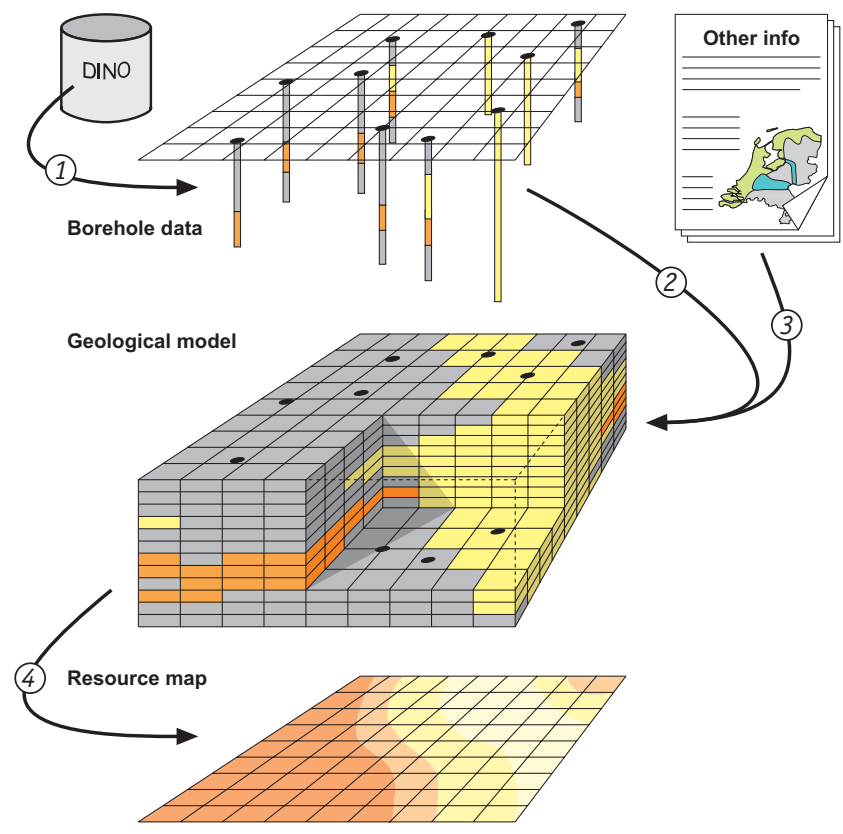

Fig. 5. Summary of the modelling procedure: 1. retrieval of borehole data from DINO, discretisation and upscaling on high-and low-resolution grids (see text for explanation); 2. interpolation of voxel attributes using linear kriging; 3. using formation-boundary surfaces as constraints. 4. Resource maps are generated according to user-defined criteria.

texture requires a lengthy ripening process. As the larger part of the country has a high groundwater table, most clay extractions are mere land-surface lowerings of 1 to $1.5 \mathrm{~m}$ (Fig. 6, left panel). Only on higher grounds in the eastern and southeastern parts of the country, clay is extracted from deeper quarries.
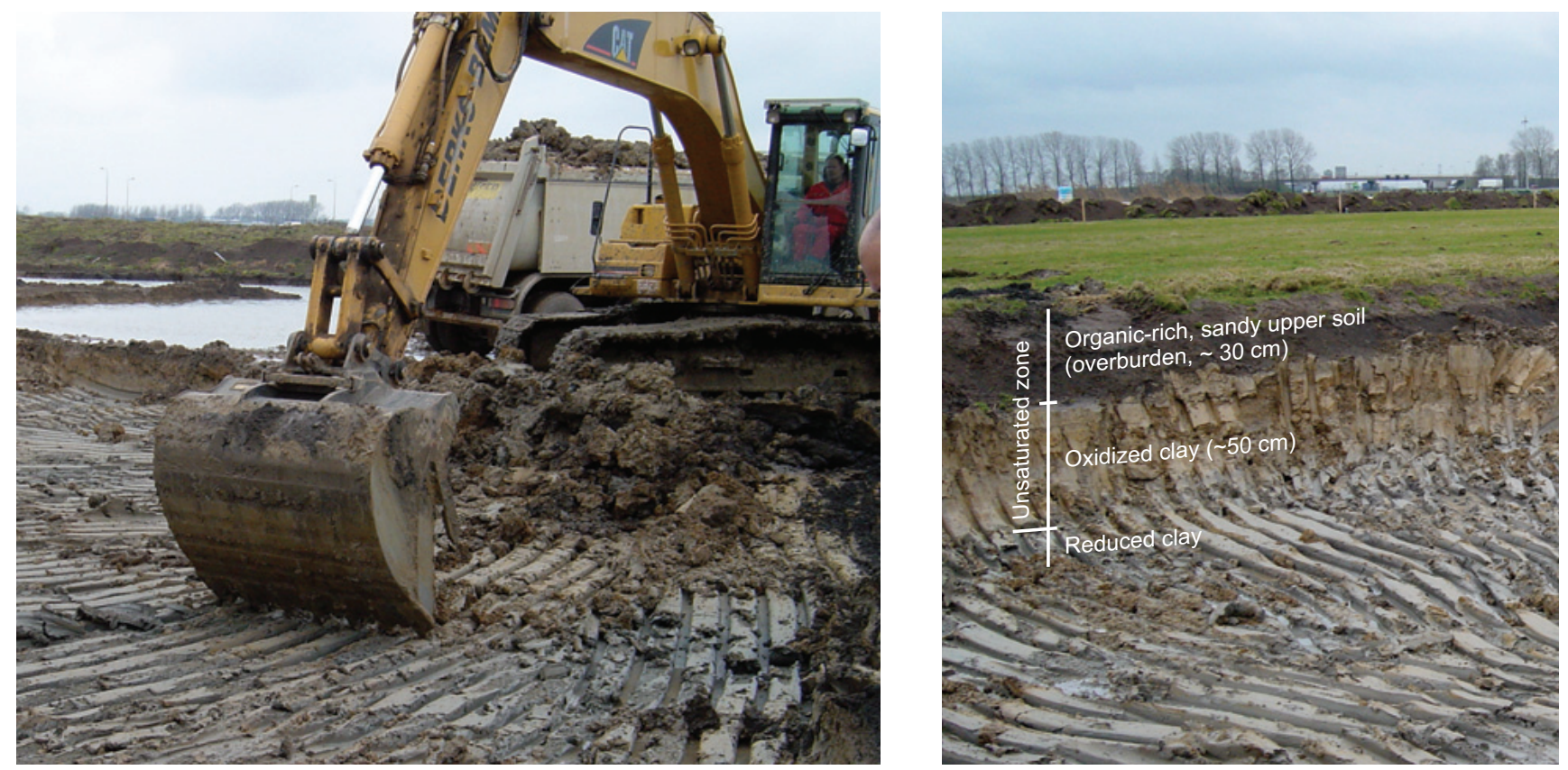

Fig. 6. Left panel: the extraction of clay using a backhoe, near the town of Arnhem (Fig. 2). Right panel: the extraction depth is about $1 \mathrm{~m}$ (including $\sim 30 \mathrm{~cm}$ of overburden); relevant lithological variation on that vertical scale is clearly visible. A caliche-horizon within the oxidised clays (not visible on this scale) presents a challenge, as it has to be removed before continuing extraction. Photo: DM. 
Backhoe operators visually select clay while extracting, using a set of rather subtle criteria that relate to the share of fines ('smoothness'), the iron content (colour), the presence of calcareous nodules and shells ('dragging striations'), etc. These properties reflect sedimentary and/or pedogenic processes, both of which introduce vertical lithological variation on the sub-metre scale (Fig. 6, right panel). Hence, the aggregates model, having a vertical resolution of $1 \mathrm{~m}$, is not detailed enough for assessing clay resources. We have therefore built a lithological model of higher resolution down to $3 \mathrm{~m}$ below land surface, with voxel dimensions of $250 \cdot 250 \cdot 0.2 \mathrm{~m}$. This depth range is covered by shallow hand-drillings (Fig. 3) that are usually well-described, in description intervals of centimetres to decimetres.

In the lowlands (corresponding approximately to the main Holocene areas in Fig. 2), a 3 m model comprises the unsaturated zone and, hence, exploitable clay resources. In the uplands, where the groundwater table is lower, deeper resources are in principle accessible. In order to account for this, a second reference surface was created by interpolating the Holocene surfaces of brook valleys, disregarding the positive topography of surrounding hills (Fig. 7). Additional model space was defined down to depths of this reference surface plus $3 \mathrm{~m}$, and filled with voxels from the aggregates model, recalculated at a $250 \cdot 250 \cdot 1 \mathrm{~m}$ resolution. The maximum model depth is $50 \mathrm{~m}$ below the surface (Fig. 8a).

The model area extends from the Dutch state boundaries with Belgium and Germany to the shoreline of the North Sea. It includes the Wadden Sea and IJsselmeer lake, rivers and other inland water bodies, below which clay resources are considered inaccessible by definition. For model-consistency reasons, surface waters were not excluded from the model area. However, no effort has been put in dealing with peculiarities of the sub-aquatic domain, such as lower data-density and active sedimentation and erosion processes.

\section{Interpolation procedures}

The original aggregates model was interpolated relative to land surface. The high resolution model and the upgraded aggregates model were both interpolated relative to Dutch ordnance datum (NAP), for better reproduction of the mostly nearhorizontal layer-cake stratigraphy of the Dutch upper Quaternary. A second improvement that was made is confining the interpolations by the formation-boundary surfaces of DGM, a national stacked 2D-grid model of the Dutch Quaternary and Tertiary (De Mulder et al., 2003; TN0, 2007b). This step was undertaken to avoid the correlation of lithologies that are adjacent but genetically unrelated. Visual inspection of the interpolation results showed that this step has significantly improved model consistency.

\section{Clay quality attributes}

In accordance with the approach to map deleterious impurities for ceramic clays, we added the occurrence of shell material and the extent to which sediment is peaty as quality attributes. In our dataset, these parameters are ideally given as abundance classes, which are semi-quantifications of visual observations. Keeping in mind the subjectivity of such classification, class 1 should be interpreted as rare ('single fragment', 'hardly observable', etc.), 2 as present ('common', 'clearly visible', etc.), and 3 as abundant ('above-average', 'omnipresent', etc.). Instead of, or in addition to lithological classification (Fig. 4, upper right panel), references to organic content may be included in descriptive text fields of our borelogs, e.g. 'rootlets' or 'plant debris'. Note that none of these attributes refer to the share of non-particulate organic carbon.

On the basis of the available information, a probability indicator for shell and peat admixture occurrence was defined and interpolated. It is set at $100 \%$ in case of abundance classes 2 and 3 or of unspecified admixture references, and at $60 \%$ in case of abundance class 1 . The latter value has been chosen primarily for its effect on the interpolation results, which should reflect the characteristics of the underlying set of observations. A $60 \%$ attribute value produces a scattered signature if isolated, while it maintains spatial continuity in case of nearby observations of shell or peat material.

Calcareous nodules are not amongst the standard parameters in our borehole descriptions, nor do they seem to have been logged consistently in descriptive text fields. We therefore did not attempt to include them as quality attribute. As a pedogenic feature, calcareous nodules occur mainly around the water table that delimits clay extraction anyway. Hence, we feel that disregarding this phenomenon presents no serious limitation to the present large-scale resource assessment. Caution should be exercised, however, in case of known watertable lowering (e.g. polder-table adjustments), which may have put calcareous nodules in the unsaturated zone.

Lowlands

'Uplands'

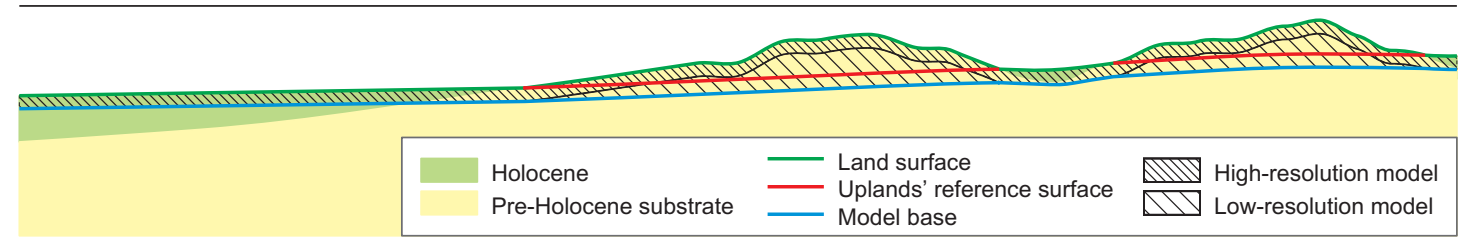

Fig. 7. Defining the model space for the clay-resource assessment (see text for explanation). 


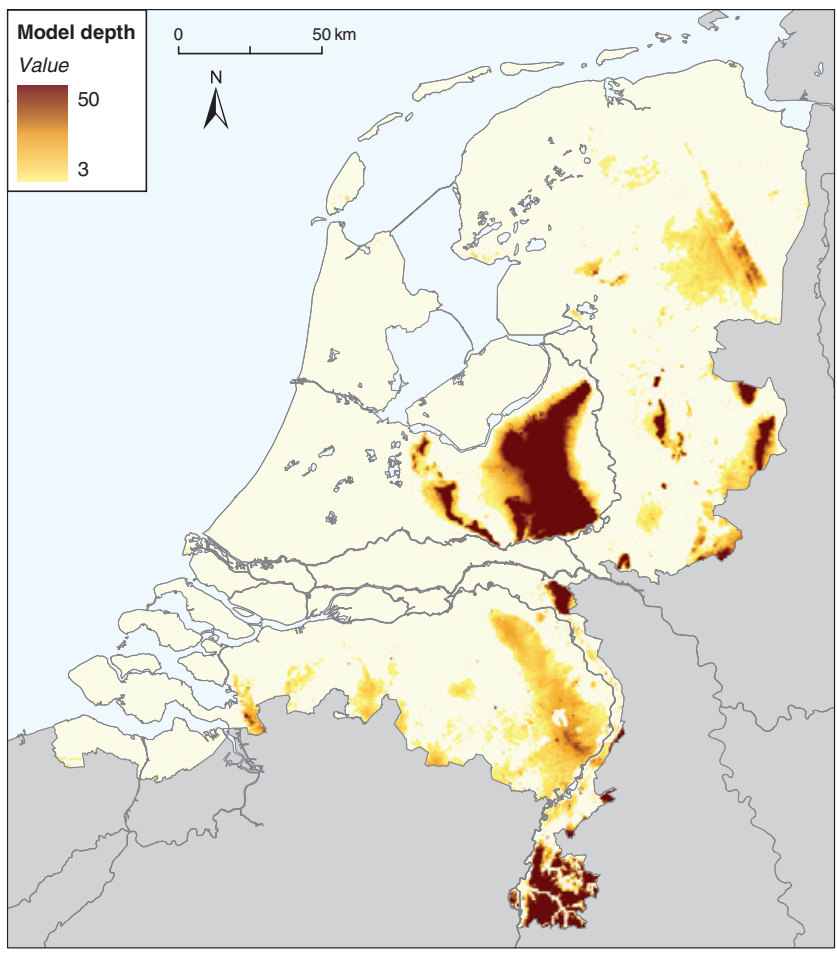

a.

Fig. 8. a. Model space dimensions (see also Fig. 7); b. the borehole density at the midplane of the model, as used for the map confidence classification ( $c$; see text for further explanantion).

\section{Exploitability criteria}

In principle, groundwater should be the first constraint to be used when assessing clay exploitability, for reasons outlined above. However, whereas the Geological Survey of the Netherlands manages a groundwater monitoring network with some 20,000 observation wells, it does not yet have national water-table grids available that can be inserted into our model. Instead of calculating exploitable clay reserves using groundwater data, we show cumulative volumes as function of hypothetical extraction depths. Other (non-hydrological) parameters that determine clay exploitability relate to lithology and resource architecture. Clay is considered exploitable unless:

- it is covered by $\geqslant 40 \mathrm{~cm}$ of peat. This criterion applies mainly to the lowlands, where peat is abundant, groundwater is high, and $40 \mathrm{~cm}$ would constitute a significant part of extractable volumes by definition.

- it is covered by $>5 \mathrm{~m}$ of non-clay material (sand in most cases). This criterion applies only in the uplands, where the resource model covers thicknesses in excess of $5 \mathrm{~m}$.

- the lithology is till (boulder clay), which was formed below the advancing Saalian ice sheet in the northern parts of the country. In our database, till classifies as loam or clay (in the latter case sometimes erroneously), and it is therefore included in the results of queries for the clayey lithologies that we use. However, we do not consider till a clay resource,

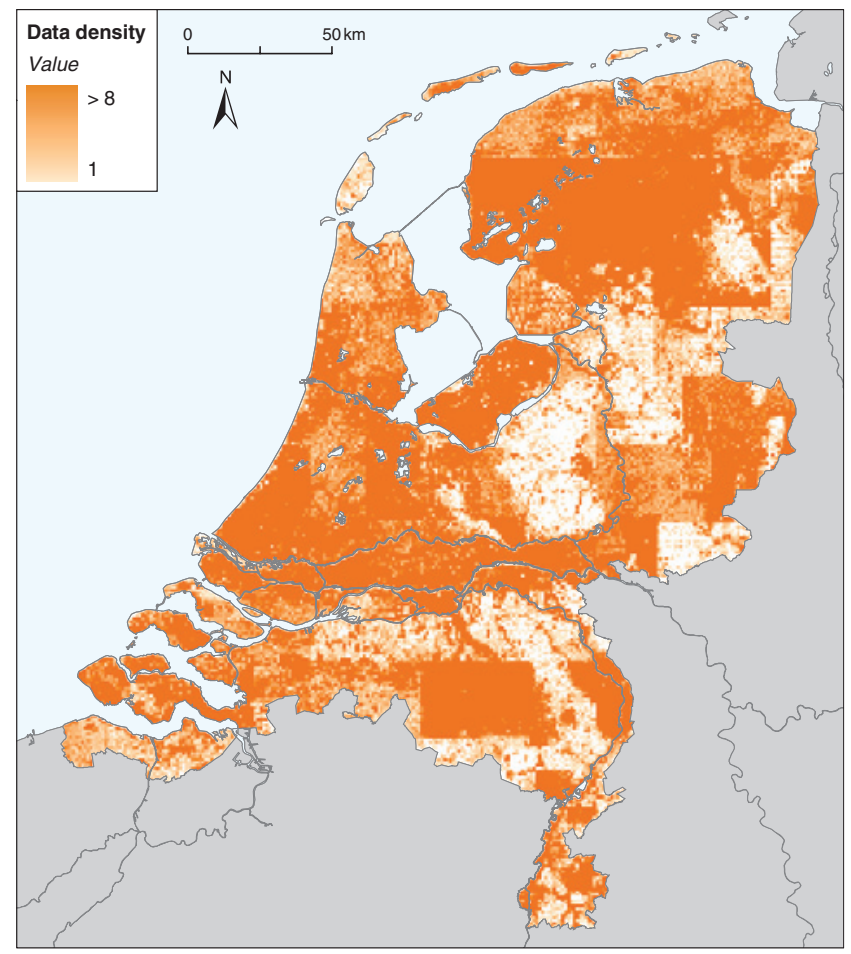

b.

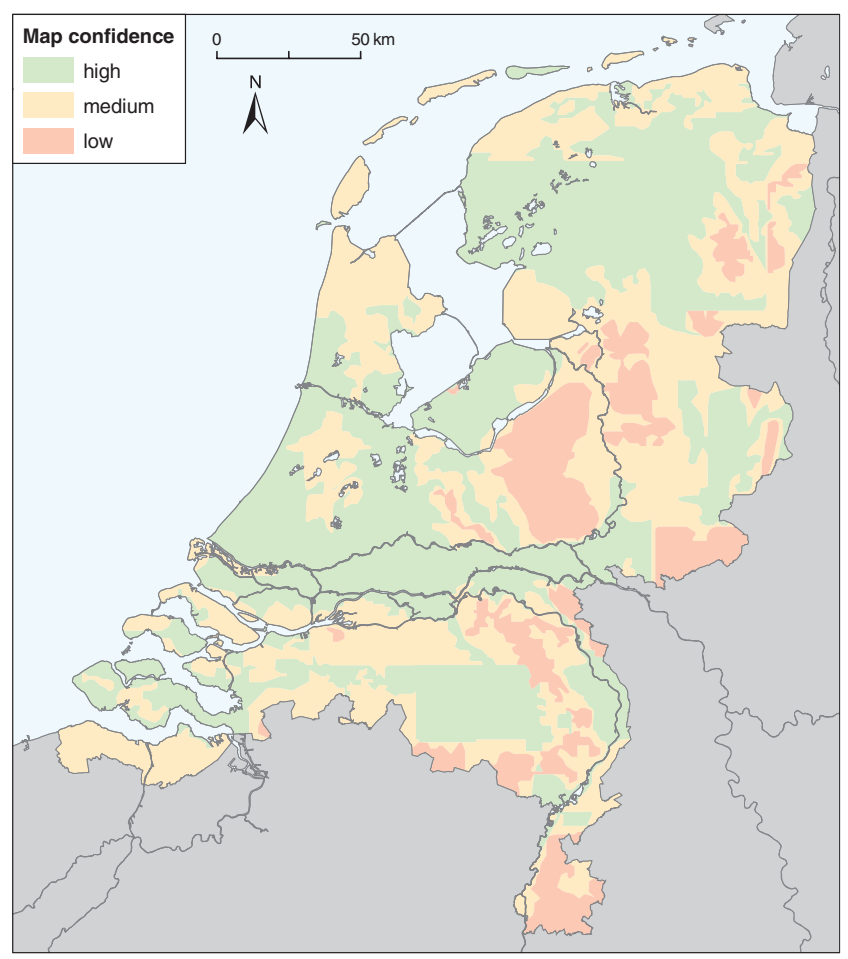

c.

even though it was in fact used historically, e.g. for the construction of the so-called 'Afsluitdijk' which separates the IJsselmeer lake from the Wadden Sea (Fig. 2; Van der Meulen et al., in press). The Saalian till is a stratigraphic unit in the official Dutch lithostratigraphic scheme (Drente Fm, Gieten Mbr; cf. De Mulder et al. 2003), so the combination of lithological and stratigraphic attributes allows for a proper identification of till in our model. 
- it belongs to the uppermost soil. The sediment classification system used in our database does not systematically include pedogenic features, and a rooted sod or an otherwise organically enriched soil horizon may not have been described properly. Ideally, it would either classify as peat or have a peaty attribute. However, if the emphasis in the description was put on the unaltered lithologies, clay may appear in the topmost model layer, whereas it is in reality never suitable for any application. We therefore discarded the topmost $20 \mathrm{~cm}$-layer of our model.

As a special resource category, the loess deposits of Limburg were included in the clay stocks as a labelled sub-volume. Being a stratigraphic unit (Boxtel Fm, Schimmert Mbr, cf. De Mulder et al., 2003), loess was identified in the same way as till.

\section{Map confidence}

Our results are based on a very large, heterogeneous dataset, which precludes a manual assessment of data quality. As a consequence, we have not been able to produce an adequate accuracy assessment as part of our modelling, which would have to involve not only the quality of the borehole data, but also that of the formation boundary surfaces that have been used. Instead, we present an a posteriori assessment of map confidence, relating to variation in data coverage and the extent to which the underlying model adequately reproduces known geological features (rather than artefacts).

A large part of the Dutch lowlands has been surveyed as part of the national $1: 50,000$ geological mapping program, which was terminated before completion in the 1990s. As a result, the shallow, high-resolution lithological model that has been constructed for these areas generally relies on densely spaced, high-quality survey boreholes. The opposite applies to the larger part of the uplands, where data is sparser and the model depth exceeds the average drilling depth. This variation is visible in Figure $8 \mathrm{~b}$, which shows data density at the midplane of the model space.

Recognisable geological features generally prevail over clear artefacts (bull's-eyes patterns etc.) in model results for areas having a midplane borehole-density of more than 5 per $\mathrm{km}^{2}$. The opposite occurs where the density is less than 1 borehole per $\mathrm{km}^{2}$. Areas with densities between 1 and 5 boreholes per $\mathrm{km}^{2}$ constitute an intermediate category, where the extent to which geological features are resolved seems to depend mainly on the complexity of the area. On the basis of these general observations, a threefold map-confidence classification (high, medium, low) was defined and used as an overlay on result maps (Fig. 8c). Confidence strictly relates to the regional scale for which the result maps are intended to be used.

\section{Results}

\section{Clay quantity}

The total volume of clay in the model space is estimated at $47.7 \mathrm{~km}^{3}$ (Fig. 9a), and $42.1 \mathrm{~km}^{3}$ when disregarding sub-aquatic clays (not shown in the figure). The distribution of clay clearly fits the general geological layout of the Netherlands. It occurs mainly in the coastal provinces, except in the dune and beach areas where sand predominates, and along the main rivers in the central parts of the country. The resource model is also consistent with regional geological features, such as channelbelt architecture, and with the effect of historical peat extraction (Fig. 10).

The geologically exploitable sub-volume, defined according to the above criteria but disregarding groundwater, is estimated at $34.7 \mathrm{~km}^{3}$, i.e. $82 \%$ of the total volume (Fig. $9 \mathrm{~b}$ ). This includes clays having thicknesses that are insufficient for economically viable extraction. When disregarding, as an indication, clays of less than $40 \mathrm{~cm}$ in thickness (yellow in Fig. 9), the exploitable volume would be reduced by $1.4 \mathrm{~km}^{3}$ (or $4 \%$ ). However, just like other primarily economical factors, we disregard resource thickness in further calculations. The volume of loess in Limburg is estimated at $3.0 \mathrm{~km}^{3}$, almost all exploitable. This amounts to 7.1 and $8.6 \%$ of the total and exploitable clay stocks, respectively.

We explored exploitability in relation to groundwater by calculating resource quantities down to an assumed groundwater table depth range. In the lowlands, we estimate it at 1 to $1.5 \mathrm{~m}$ below the surface, in accordance with common clay extraction depths in this type of area. The situation in the uplands is less straightforward, so we approximated exploitability by calculating resources with respect to both land surface and the aforementioned second reference surface (see Fig. 7). The average of these results, i.e. 12.3 to $18.0 \pm 2.0 \mathrm{~km}^{3}$ for the chosen depth range, is our best guess of the exploitable amounts of clay in the Netherlands (Fig. 11).

About $0.7 \mathrm{~km}^{3}$ of clay is present on the embanked floodplains of the Rhine and Meuse, the 'classical' resource area for the structural-ceramics industry (see Fig. 2). Virtually all of this clay occurs in a top layer of 1 to $1.5 \mathrm{~m}$ that is unsaturated unless river discharges are high, so most of it is exploitable. Embanked-floodplain clays are currently at risk of being removed for river-widening purposes (Van der Meulen et al., 2006), without full consideration of their value as strategic resource.

\section{Clay quality}

Clay in the fine resource category $\left(18.3 \mathrm{~km}^{3}, \sim 43 \%\right.$ of the total reserve in the model volume for land areas) is limited to the fluvial plains and some landward parts of the coastal zone (Fig. 12a). Both near the coast and in the uplands, clay is 


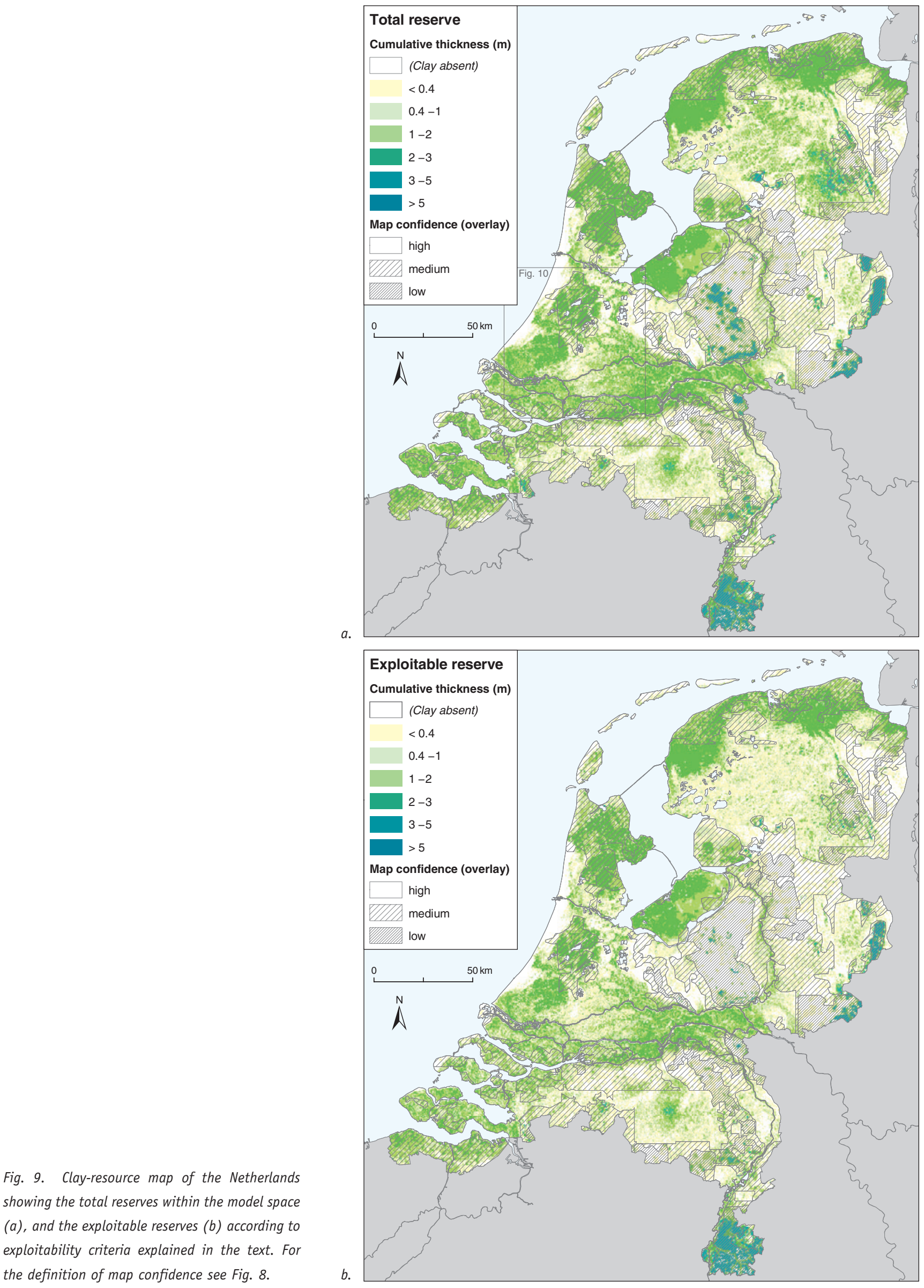

Fig. 9. Clay-resource map of the Netherland showing the total reserves within the model space (a), and the exploitable reserves (b) according to the definition of map confidence see Fig. 8. 


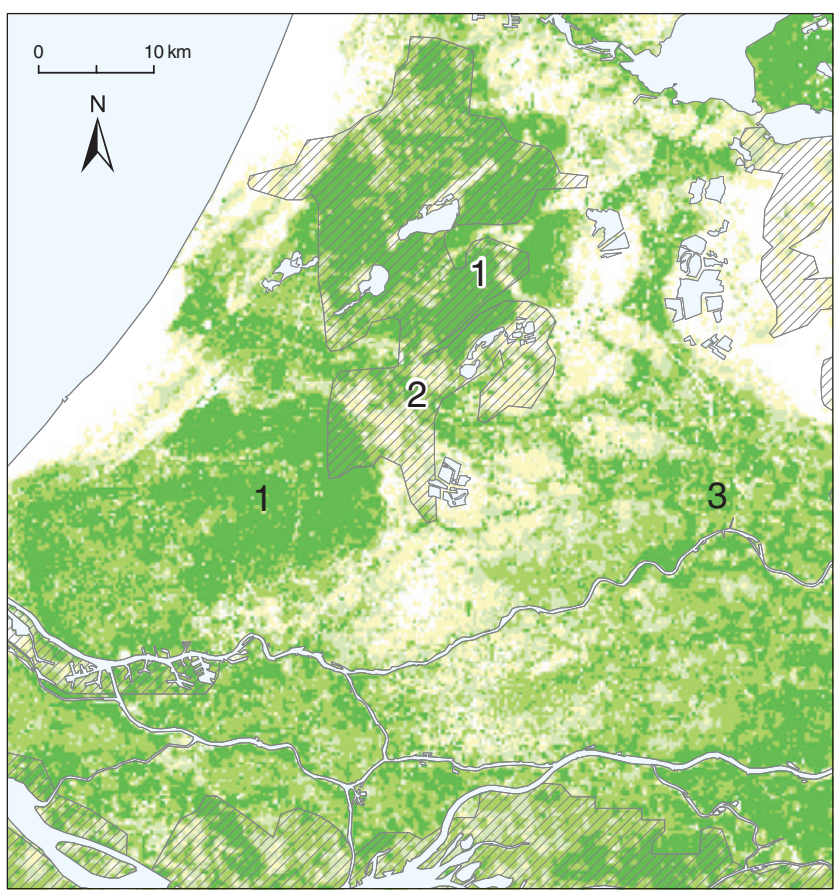

Fig. 10. Detail of the clay-resource maps of the Netherlands (see Fig. 9 for location and legend), showing a number of adequately reproduced geological features: 1. clay surfacing as a result of extraction of the overlying peat in mediaeval times; 2 . the tract of a former Rhine distributary; 3. channel-belt architecture below the Rhine-Meuse river plain.

predominantly silty or sandy. As both the coarse and the fine resource categories have been used, historically and present (as can be inferred from Fig. 2), we did not attempt to interpret coarseness in terms of a limitation to applications.

As expected, consistently high shell-occurrence probabilities are limited to the coastal area (Fig. 12b). Within this domain, the highest values are observed in former peat extractions, where marine clays have been uncovered with higher shell contents than most of the superficial clays occurring elsewhere. Scattered higher shell probabilities in fluviatile and other terrestrial environments reflect observed occurrences of land molluscs, which are thin-shelled and less problematic to ceramic-product

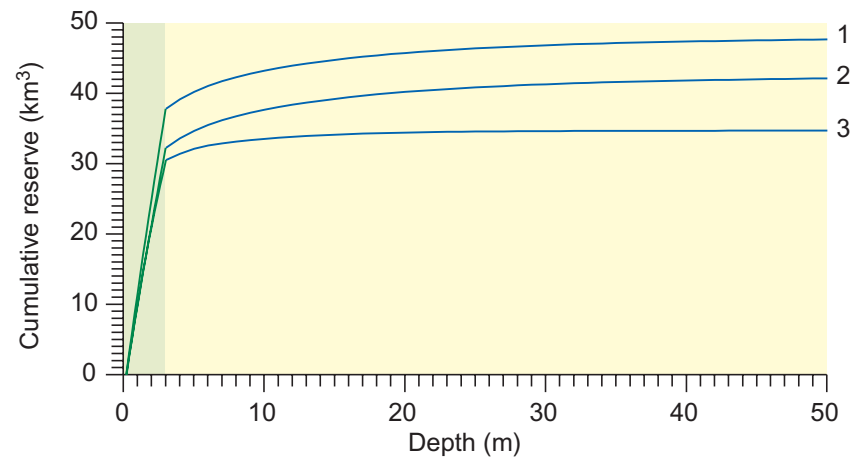

fabrication than marine shells. Organic debris occurs in a wider zone than shells; in fact, only till, loess and the clays in the upstream Rhine and Meuse areas have low abundances (Fig. 12c).

According to our data, and based on the joint probability of encountering shell or organic material, $32 \%$ of the exploitable clay (as shown in Fig. 9) would disqualify as ceramic material (Fig. 13). This is most probably an underestimate, as the chances that these admixtures are present but unaccounted for in borehole descriptions are bound to exceed those of the opposite situation. If we completely disregard areas where the probability of encountering deleterious impurities exceeds $25 \%$ or $10 \%$, in order to explore the effect of this underestimation, 44 or $56 \%$ of the clay-resource would have to be discarded, respectively. It is recommended to interpreted Fig. 13 qualitatively, keeping underestimation in mind and focussing on the overall image. On that level, the map is consistent with the main ceramic-clay resource areas, which are situated in the upstream Dutch Meuse and Rhine rivers, easternmost Gelderland and Overijssel, and southern Limburg (Fig. 2).

\section{Spatial limitations}

$5 \%$ of the geologically exploitable clay is situated below builtup areas, and 21\% occurs below areas of the so-called Ecological Main Structure ('Ecologische Hoofdstructuur', Anonymous, 2004; Fig. 13, inlay). Other than for aggregates, clay resources in the latter category should not be considered off limits by definition. Clay extraction is less controversial than most other forms of mineral extraction, given the small scale of most operations and the favourable conditions this presents for site remediation. Because of this, clay extraction is quite commonly coupled to nature development, ever since the WWF and the industry reached a co-operation agreement in 1994 (based on a plan presented by Helmer et al. 1992).

Beyond constraining extraction depths, groundwater may limit clay extraction in two types of situation. Where clay confines a shallow artesian aquifer, its (partial) removal may lead to seepage. Caution should be exercised, for example, in

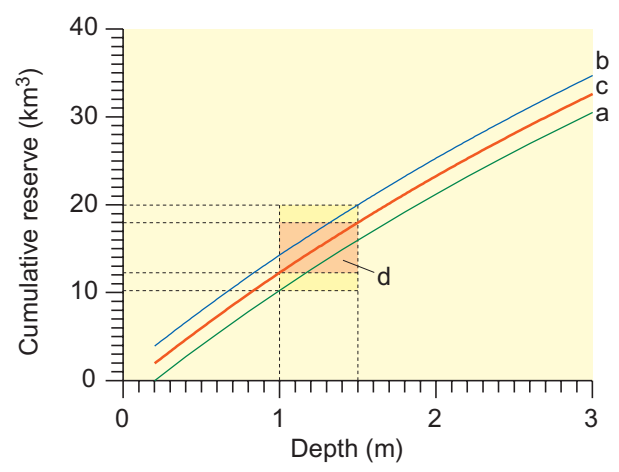

Fig. 11. Clay volumes as a function of depth. Left panel: green shading and lines are used for the vertical extent of the high-resolution model; yellow shading / blue lines for extent of the low-resolution model; 1 . the total volume of clay in the model space; 2. idem, disregarding sub-aquatic occurrences; (3) the exploitable subvolume (disregarding groundwater). Right panel: a. exploitable volumes down to $3 \mathrm{~m}$ below the surface; $b$. idem, down to $3 \mathrm{~m}$ below the reference surface (see text and Fig. 7 for explanation); c. average of a and $b ; d$. best guess of the exploitable clay volumes in the Netherlands. 
a.

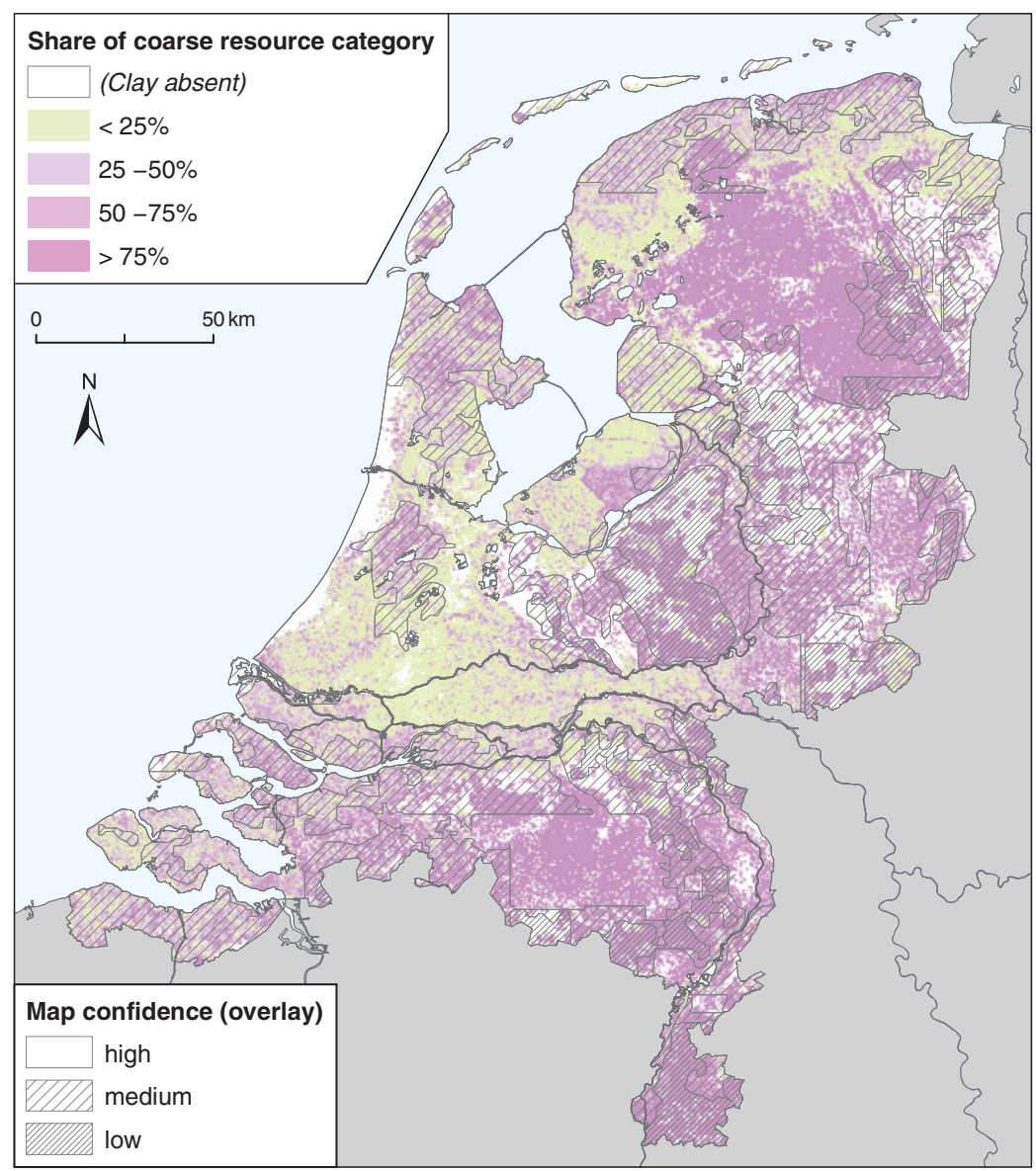

Fig. 12. Clay-quality maps showing the share of the coarse clay-resource category as explained in the text (a), and the occurrence probabilities for shell material (b) and peat or plant fragments (c; next page). All values apply to the entire clay volume in the model space (Fig. 9a).

For the definition of map confidence see Fig. 8.

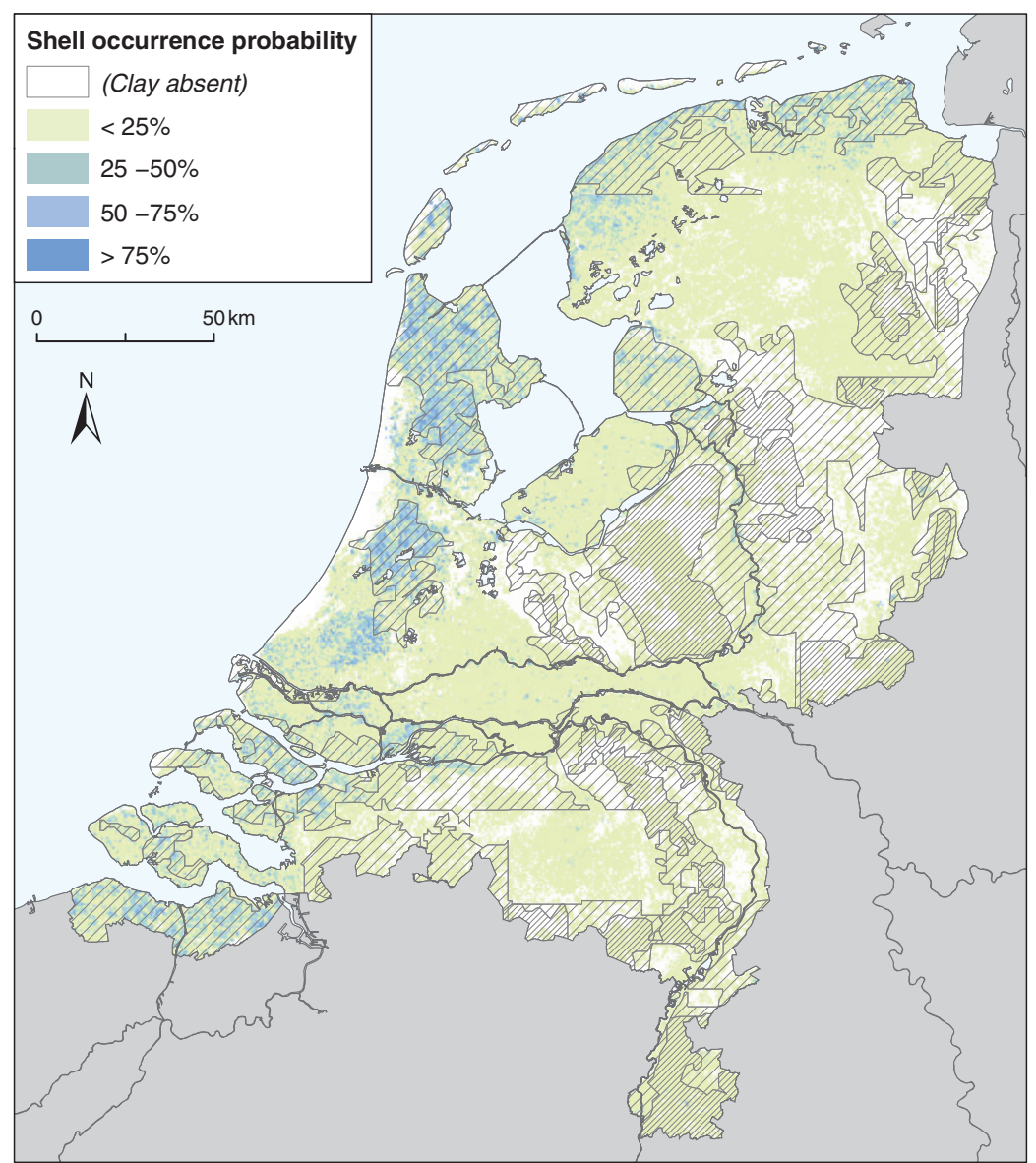




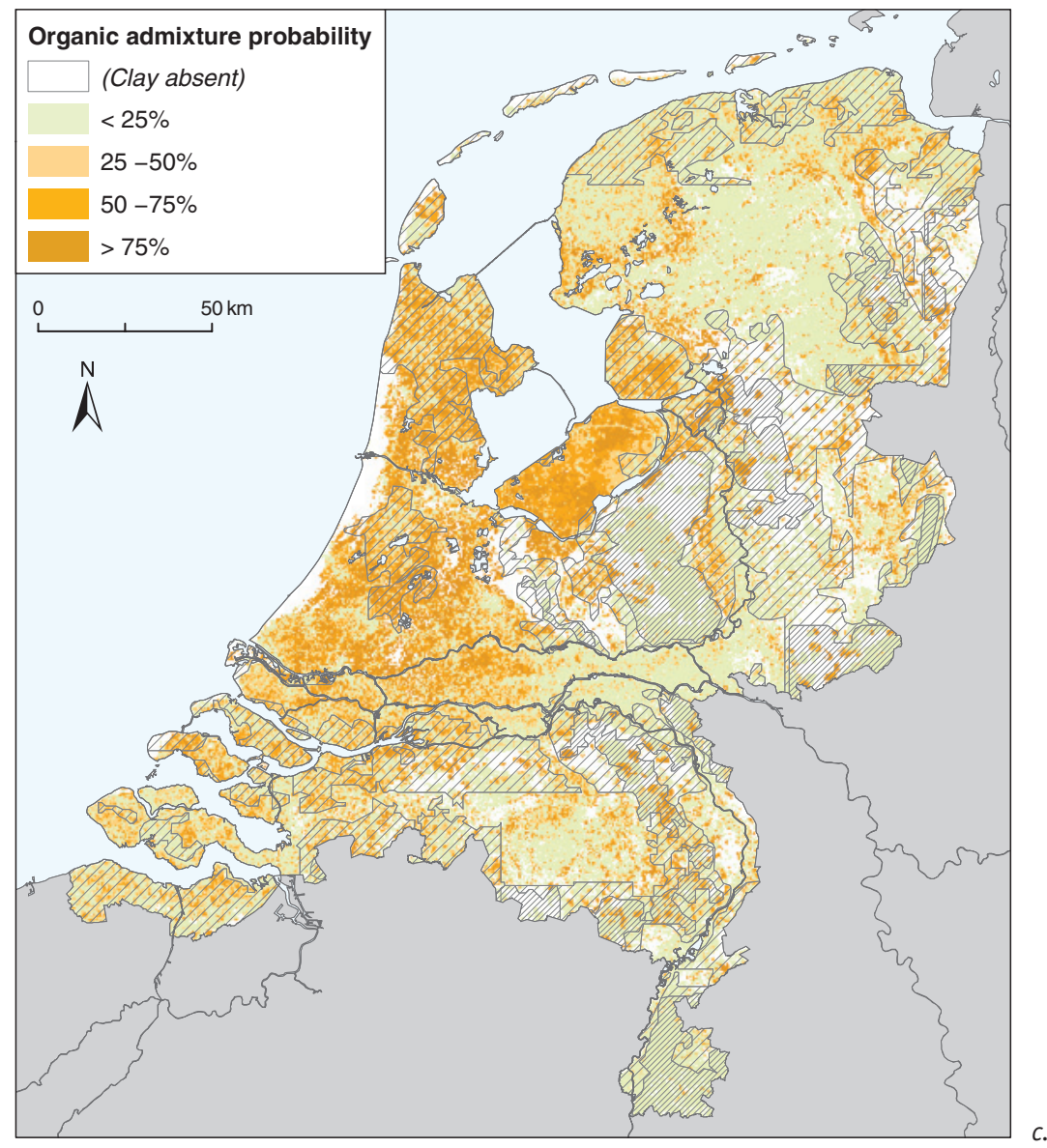

Fig. 12. (continued)

case of Holocene sandy channel-belt deposits overlain by floodplain fines in polder areas. A similar caveat applies to a peat-clay sequence on top of an artesian aquifer, in which case removal of clay may lead to heave and seepage. This problem applies, roughly, in and around the peaty zones in the coastal provinces (Fig. 2).

\section{Concluding remarks}

Clay occurs quite abundantly in the coastal zone and along the rivers Rhine and Meuse. Potential ceramic clays occur in the upstream parts of these rivers, and in the central-easternmost parts of the country. This study has improved our appraisal of Dutch clay resources, and the results will be used to take the occurrence of clay into consideration in land-use planning. Most limitations of our modelling methods and yield calculations can and will be addressed when working on local scales, handling fewer data. Examples of this are the incorporation of groundwater data, and refined exploitability criteria, which can be tuned to local geological characteristics such as the sedimentary setting and pedogenic processes.

Exploitable clay volumes correspond to roughly 6000 annual consumption equivalents. Even when considering that the larger part of this amount is probably unsuitable for firing, this implies that clay is not a scarce resource and supplies should present no problem in the near future.

\section{Disclaimer and acknowledgements}

Although the authors adhere to its basic principles, this study does not formally comply with the Code for Reporting of Mineral Exploration Results, Mineral Resources and Mineral Reserves (Anonymous, 2001). In the terms of this code, our study would classify as a reconnaissance mineral resource, apt for mineral or spatial planning purposes by the government. Note that our results are not to be used for the purpose of (a) informing investors or potential investors and their advisers or (b) satisfying regulatory requirements.

This study is part of the development of 'Delfstoffen Online / Minerals Online' (TN0, 2007a), which is financed by VIB0, a research programme in support of minerals planning funded by the Ministry of Transport, Public Works and Water Management and the joint provinces (contract DWW-2798). The authors wish to thank Hans Pietersen (Road and Hydraulic Engineering Institute, Delft, NL), Dick van Leeuwen (Dekker Van de Kamp, Oosterhout, NL), Hans van Wijck (TCKI, Velp, NL), and their colleagues Sytze van Heteren, Jeroen Schokker, Marco de Kleine, Hans Veldkamp, Ipo Ritsema, Meindert van den Berg and Jenny Hettelaar for helpful suggestions. 
Fig. 13. The joint probability of encountering shell or organic material within the geologically exploitable stock (Fig. 9b). The inlay shows the Ecological Main Structure referred to in the text. For the definition of map confidence see Fig. 8.

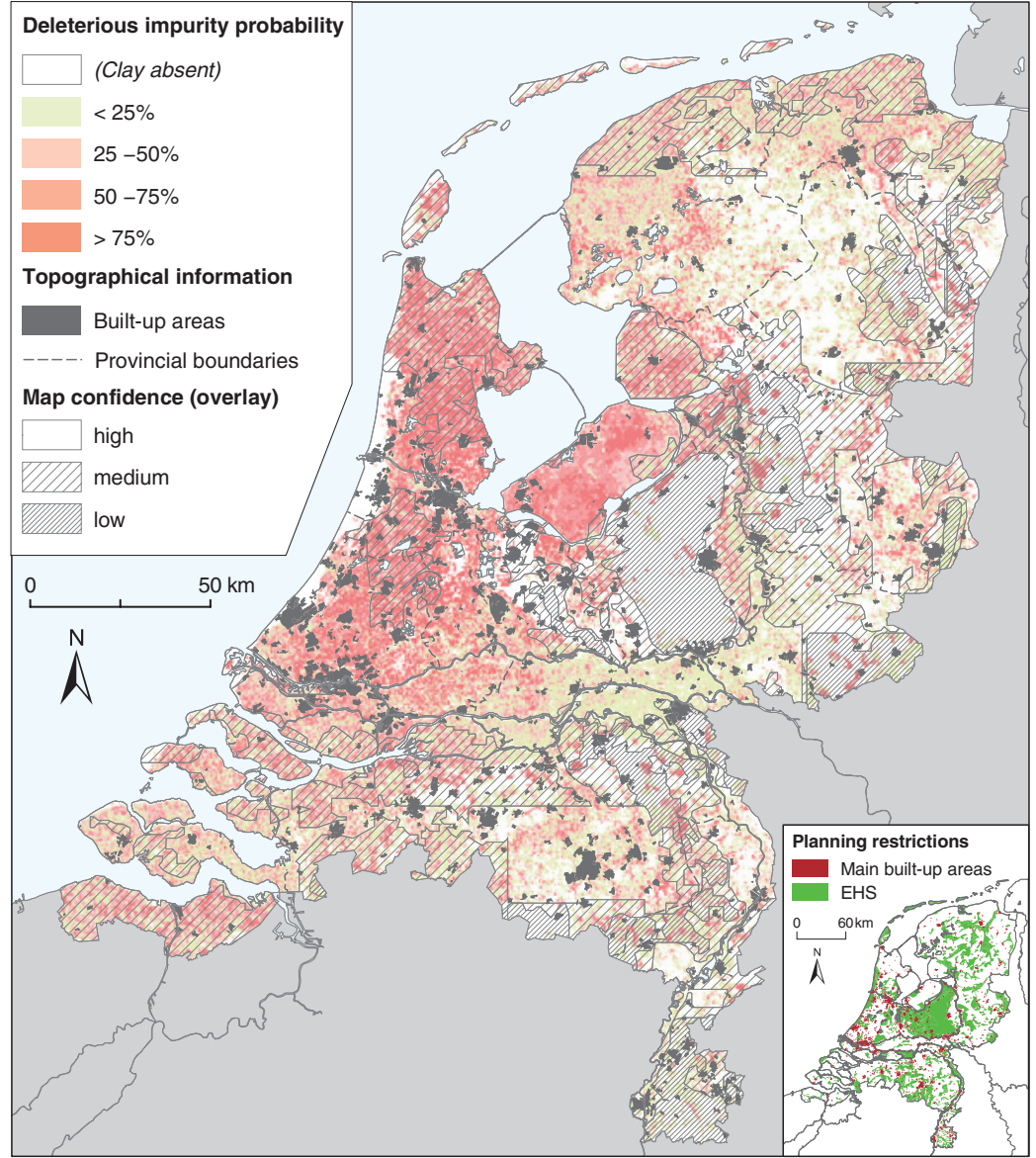

\section{References}

Anonymous, 1989. NEN 5104:1989, Geotechnics; Classification of unconsolidated soil samples. Netherlands Normalisation Institute (NEN; Delft, NL): 24 pp.

Anonymous, 1990. NEN 5104:1989/C1, Geotechnics; Classification of unconsolidated soil samples (amendment). Netherlands Normalisation Institute (NEN; Delft, NL): 1 pp.

Anonymous, 2001. Code for reporting of mineral exploration results, mineral resources and mineral reserves (the reporting code). Institution of Mining and Metallurgy (London, UK), European Federation of Geologists (Brussels, B), Geological Society of London, Institute of Geologists of Ireland (Dublin, IE): $34 \mathrm{pp}$.

Anonymous, 2004. Nota Ruimte. Ministry of Spatial Planning, Housing and the Environment (The Hague, NL): 50 pp.

De Mulder, E.F.J., Geluk, M.C., Ritsema, I., Westerhoff, W.E. \& Wong, Th.E., 2003. De ondergrond van Nederland. Wolters Noordhof (Groningen, NL): 379 pp.

Helmer, W., Klink, A., Overmars, W. \& Litjens, G., 1992. Levende Rivieren (in Dutch). World Wildlife Fund (WWF) (Zeist, NL): $28 \mathrm{pp}$.

Kooijman, J., 2003. Haalbaarheidsstudie Authentieke Registratie DINO Eindrapportage (in Dutch). TNO Built Environment and Geosciences (Utrecht, NL): $42 \mathrm{pp}$.

Peersmann, M.R.H.E., 2005. Geo-Informatieprogramma 2005 (Geo-Information program 2005, in Dutch). TNO Built Environment and Geosciences (Utrecht, $\mathrm{NL}): 200 \mathrm{pp}$.
Sigmond, G.J.A, Hund, J.B.A. \& Van der Meulen, M.J., 2001. Ruimte voor Rijntakken: inventarisatie kleivoorkomens. Road and Hydraulic Engineering Institute (Delft, NL) report DWW-2001-094 / Publicatiereeks Grondstoffen 2001/11: 24 pp.

TNO, 2007a. Delfstoffen Online (Minerals Online, web service for minerals information, in Dutch). www.delfstoffenonline.nl.

TNO, 2007b. Dinoloket (internet portal for geo-information). dinoloket.tno.nl.

Van der Meulen, M.J., Koopmans, T.P.F. \& Pietersen, H.S., 2003a. Construction raw materials policy and supply practices in Northwestern Europe. In: Elsen, J., Degryse, P. (eds): Industrial Minerals - Resources, Characteristics and Applications. Aardkundige Mededelingen 13: 19-30.

Van der Meulen, M.J., De Lang, F.D., Maljers, D., Dubelaar, C.W. \& Westerhoff,

W.E., 2003b. Grondsoorten en Delfstoffen bij Naam (in Dutch: a dictionary of soil materials and quarry products). Road and Hydraulic Institute (Delft, NL) and TNO Built Environment and Geosciences (Utrecht, NL), ISBN 90-3695549-1: $96 \mathrm{pp}$.

Van der Meulen, M.J., De Kleine, M.P.E., Veldkamp, J.G., Dubelaar, C.W. \& Pietersen, H.S., 2004. The sand extraction potential of embedded land surface lowering in the Netherlands. Netherlands Journal of Geosciences 83(2): 147-151.

Van der Meulen, M.J., 2005a. De bouwgrondstoffentoets doorgrond. TN0 Built Environment and Geosciences (Utrecht, NL), Report NITG 05-035-A: 30 pp. 
Van der Meulen, M.J., 2005b. Sustainable mineral development: possibilities and pitfalls illustrated by the rise and fall of Dutch mineral planning guidance. In: Petterson, M., McEvoy F, \& Marker, B.R. (eds): Sustainable minerals operations in the developing world. Geological Society of London (UK), Special Publications 250: 225-232.

Van der Meulen, M.J., Van Gessel, S.F. \& Veldkamp, J.G., 2005. Aggregate resources in the Netherlands. Netherlands Journal of Geosciences 84(3): 379-387.

Van der Meulen, M.J., Broers, J.W., Hakstege, A.L., Van Heijst, M.W.I.M., Koopmans, T.P.F. \& Pietersen, H.S., in press. Surface Mineral Resources. In: Wong, Th.E., Batjes, D.A.J. \& De Jager, J. (eds): The Geology of the Netherlands. Royal Netherlands Academy of Arts and Sciences (KNAW; Amsterdam, NL), pp. 313-329.

Van der Meulen, M.J., Rijnveld, M., Gerrits, L.M., Joziasse, J., Van Heijst, M.W.I.M. \& Gruijters, S.H.L.L., 2006. Handling sediments in Dutch river management: the planning stage of the Maaswerken river widening project. Journal of Soils and Sediments 6(3): 163-172.

Van der Zwan, J.T., 1990. Inventarisatie van kleivoorkomens in Nederland geschikt voor de grof-keramische industrie en de dijkbouw. Road and Hydraulic Engineering Institute (Delft, NL) report TW-R-89-4: 36 pp.

Van Wijck, J.H., 1997. Grofkeramische kleien in Nederland. Klei, Glas, Keramiek 18 (10): 14-17.

Weerts, H.J.T., Schokker, J., Rijsdijk, K.F. \& Laban, C., 2004. Geologische overzichtskaart van Nederland / Geological map of the Netherlands. TN0 Built Environment and Geosciences - Geological Survey of the Netherlands (Utrecht, NL). 